\title{
Loving GOD, Loving Others: The Evil of Hatred by Accidental Differences in Humankind
}

\author{
Michael A. Milton, $\mathrm{PhD}^{1}$ \\ ${ }^{1}$ Affiliation not available
}

July 7, 2021

\begin{abstract}
The rise of ideologies in the West that promote prejudicial treatment of others based on accidental (humanly uncontrollable) features (distinguishing ethnic physical traits, geographic origin, physical or mental capacities, or native cultures, viz., Western Civilization, that in all of its vicissitudes, has produced distinctive behavioral, socio-religious, and intellectual norms) is an illogical, cruel, and nationally self-destructive worldview that must be exposed and rejected. The premise of "races" of human beings (Caucasian race, negroid race, mongoloid race, etc.) , rather than the "race of Mankind," male and female, all originating from a common set of ancestors, created by God, with "in-species" genetic variety (e.g., melanin production creating darker or lighter skin color) is not only unsupported by the teachings of the Old and New Testaments, but singled out as sins against God. The author examines a recent case of a medical doctor dreaming of murdering white people. The statement is considered from both scientific and spiritual viewpoints. The author cites personal experience in the United States military, as well as peer-reviewed articles, to establish the hypothesis that the rise of violent tribalism ("Balkanization") produces Socialistic authoritarianism, which forcibly reunites divided "tribes" under the flag of autocratic rule. This opinioneditorial article concludes by asserting that the Gospel of Jesus Christ is the powerful antidote that liberates people from the pestilent consequences of original sin to discover authentic fraternity in our common Imago Dei (the image of God in Man), and transformative freedom from the effects of the Fall, i.e., to embrace and be embraced by a divine love that transcends our sin. Only in knowing such love can we be free from the hatred that divides, the bitterness that excludes, and the pain and sorrow that inevitably follows.
\end{abstract}

\section{Preface}

Let's begin with two statements, two thoughts, two convictions, and one set of diametrically opposite worldviews:

If someone says, "I love God," and hates his brother, he is a liar; for he who does not love his brother whom he has seen, how can he love God he has not seen? And this commandment we have from Him: that he who loves God must love his brother also" (1 John 4:20-21 NKJV(Bible 1982)

Here is the other statement:

"I had fantasies of unloading a revolver into the head of any white person that got in my way, burying their body and wiping my bloody hands as I walked away relatively guiltless with a bounce in my step"(Lindquist 2021).

The distance between the two statements - one born out of divine love and the other out of mortal hatred-is as far as heaven is from hell. The psychiatrist's Freudian "id" is as bloated with self as her soul is depleted 
by sin. Even if she chose this wish-narrative as a shamanic therapy to excise the accumulated infection from a spiritual pathology, the effect is the same: self-satisfaction by homicide.

The former? Healing. Hopeful. Redemptive. The latter? Troubling. Chilling. Inconceivable. How does a human being come to such a place?

\section{The (Hopefully) Obvious Concern}

That a physician and scholar should hold a lecture, "The Psychopathic Problem of the White Mind," in a prestigious school of medicine (Yale) to express her innermost feelings (not tested hypotheses, as one might expect from a scientist) about race through rhetorical exclusion - to underscore the dissimilarities between two groups of people for the purpose of denying the benefits of community, viz., a degree of life, liberty, and happiness-(Angelopoulou 2001) would be almost inconceivable. Almost-because that same physician is actively (even if unwittingly) fermenting social anarchy based on the well-honed strategies of pitting people against people of the same nation using skin color (and a predictable socio-historical revisionist history to go with it, e.g., the 1619 Project)(Woodson Sr 2021). Division by identity-hatred is a well-documented méthode de succès (in the same way that the destruction of the Twin Towers on $9 / 11$ was a success for the murderous terrorists who planned and executed the atrocity). The doctor's advocacy of murder as a sort of self-prescribed amphetamine to quench her homicidal yearnings (and, by her admission, to overcome her intense anxiety provoked by a perceived incorrigible presence of "whiteness"), based on a group of people of the same skin color, is, at once, repulsive and appalling. There is absolutely no fear of cliché in deducing, "If a medical doctor teaching before an elite graduate school audience can openly share her 'dream' of murdering other human beings based on their genetically predisposed and comparatively lower levels of melanin, how many other madmen will carry it out?" Skin color has been demonstrated to be the product of a complex genetic journey that involves both human migration, generations of genetic dynamics, and the adaptability of human beings to live in certain environments (Relethford 1997).
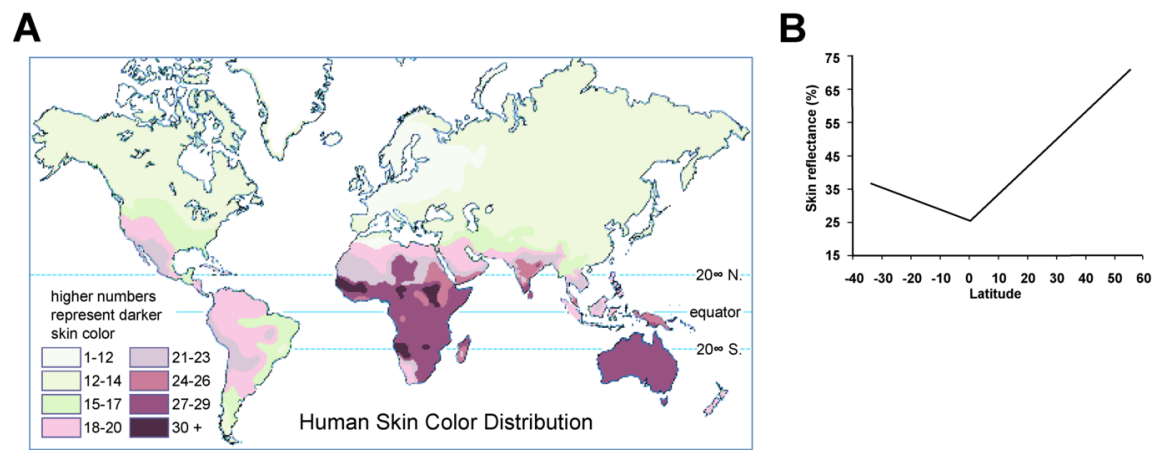

Figure 1: Summary of 102 skin reflectance samples for males as a function of latitude, redrawn from Relethford (1997). https://doi.org/10.1371/journal.pbio.0000027.g002.

The human pigmentation journey continues as globalization disperses highly isolated skin types. Melanin pigmentation types, eumelanin (darker) and pheomelanin (lighter), produce the skin color in individuals, but much work remains in learning about why we should care. For instance, the abundance of pheomelanin could increase cancer rates in lighter-skinned, freckled individuals of, e.g., Irish descent (Bastiaens et al. 2001). Those with increased levels of eumelalin tend to have greater resistance to malaria, and related health benefits by settling near the earth's equator. What unique health concerns do these families of Man develop in northern climates? What about the death rate of the Boers (Dutch farmers in South Africa) from melanoma? These are some of the real issues of "race," if you prefer that term for the various people groups of humankind. Ethnicity, or "color," as the psychiatrist chose to describe the differences in human beings, 
is not only a social construct but is also a physiological reality; a reality that deserves scientific inquiry for the greater flourishing of our one race of Mankind. If the Yale School of Medicine is interested in race and medicine, perhaps inviting a researcher to lecture on the latest work being done on pigmentation and disease would be better than hosting a practicing racist. Of course, such subject matter would be scientific rather than social, or political. However, the Dean of Yale Medical School could be spared the embarrassing optics, and questionable association with a psychiatrist dreaming of killing white people. Or, maybe hosting an alleged racist just doesn't matter anymore.

So, the concept of moral depravity or superiority by the observation of melanin measurements is incredibly naïve if not downright ignorant. However, Dr. Aruna Khilanani, who lectured at the Child Study Center at Yale School of Medicine, confirmed to all (including, regrettably, our future pediatricians) a sobering maxim: Yesterday's conspiracist is today's voice of reason.

\section{The Biblical Truth about Race}

None of the scientific observations we have noted contradict the record of Scripture.

Even a cursory survey of the Old and New Testaments reveals a unified truth: God created Mankind ("ad-am" in Hebrew), male and female. Sin, rebellion against God, led to the first great migration away from Eden. This was, as John Milton (1608-1674) famously, Paradise Lost (1667). Through several significant events in world history (the global Flood and aftermath), God made from the remnant of Mankind-Noah, his wife, his sons and their wives - a variety of families, nations, ethnicities, and other definitions of people groups. These varieties of the one "species" came about, in great part, when God divided humanity into families, and dispersed them across the earth. Though Mankind sinned against God, the Lord God is gracious and intends for a Paradise Regained (John Milton, 1671). God loves His creation. However, the Bible is clear that God has prioritized His most sacred creation, Mankind. For Mankind has the image of God, the Imago Dei. Humanity, all of us, have communicable attributes of God (we lack and can never attain the incommunicable attributes, e.g., omniscience; We are not and can never be a god). Yet, we carry a reflection of His image, marred as that image may be by sin. People, all people, are precious to God. He promised that through Abraham, God would bring blessing to the entire earth, that is, to the one human race. God accomplished this through Israel, ethnic Jews of old, some faithful to God and some not; who became the birthing nation to the Messiah, our Lord Jesus Christ, who came to fulfill the Covenant, meet the demands of God's holy

law, and live a sinless life offered up for our sins on a cross. By faith in Jesus Christ, any human being who calls on the name of the Lord Jesus will be saved. By the grace of God alone and without human contribution to salvation, Jesus Christ's righteousness is imputed to our account, and Christ's atonement on the cross is accounted as sufficient to pay for our sins.

Here is a brief on the Bible and Race (with the author's emphases):

\section{One Race (Genesis 1:26 KJV)(Norton 2005)}

So God created man ['āam] in his own image, in the image of God he created him; male and female he created them.

\section{Paradise Lost (Romans 8:19-23 ESV)(Sproul 2015)}

For the creation was subjected to futility, not willingly, but because of him who subjected it, in hope that the creation itself will be set free from its bondage to corruption and obtain the freedom of the glory of the children of God. For we know that the whole creation has been groaning together in the pains of childbirth until now. And not only the creation, but we ourselves, who have the first fruits of the Spirit, groan inwardly as we wait eagerly for adoption as sons, the redemption of our bodies. 


\section{Global Catastrophe (Genesis 10:1-5 ESV; the Flood and the rebirth of humanity)}

These are the generations of the sons of Noah, Shem, Ham, and Japheth. Sons were born to them after the flood. The sons of Japheth: Gomer, Magog, Madai, Javan, Tubal, Meshech, and Tiras. The sons of Gomer: Ashkenaz, Riphath, and Togarmah. The sons of Javan: Elishah, Tarshish, Kittim, and Dodanim. From these, the coastland peoples spread in their lands, each with his own language, by their clans, in their nations.

\section{Babel and Human Migration (Genesis 11:4, 6, 8 ESV; The building of a great structure, prior to the rebellious desire for a unified front against God)}

Then they said, "Come, let us build ourselves a city and a tower with its top in the heavens, and let us make a name for ourselves, lest we be dispersed over the face of the whole earth."

And the Lord said, "Behold, they are one people, and they have all one language . .

So the Lord dispersed them from there over the face of all the earth, and they left off building the city.

\section{A Divine Covenant to the Earth (Genesis 12:3; John 3:16, 17 ESV)}

. . . and in thee [Abraham's nation, Israel, and the land (their earthly home) that will bring forth the Messiah] shall all families of the earth be blessed.

"For God so loved the world, that he gave his only Son, that whoever believes in him should not perish but have eternal life. For God did not send his Son into the world to condemn the world, but in order that the world might be saved through him.

People Groups (Jeremiah 13:23; Acts 10:28; 17:26; Romans, 2:11; 10:12-13; Galatians 3:28; Colossians 3:11 ESV)

Can the Ethiopian change his skin or the leopard his spots? Then also you can do good who are accustomed to do evil.

And he said to them, "You yourselves know how unlawful it is for a Jew to associate with or to visit anyone of another nation, but God has shown me that I should not call any person common or unclean.

And he made from one man every nation of mankind to live on all the face of the earth, having determined allotted periods and the boundaries of their dwelling place,

For God shows no partiality.

For there is no distinction between Jew and Greek; for the same Lord is Lord of all, bestowing his riches on all who call on him. For "everyone who calls on the name of the Lord will be saved."

Here there is not Greek and Jew, circumcised and uncircumcised, barbarian, Scythian, slave, free, but Christ is all and in all.

\section{Racism is Condemned (Leviticus 19:33-34; James 2:4; 8,9 ESV)}

"When a stranger sojourns with you in your land, you shall not do him wrong. You shall treat the stranger who sojourns with you as the native among you, and you shall love him as yourself, for you were strangers in the land of Egypt: I am the Lord your God.

Have you not then made distinctions among yourselves and become judges with evil thoughts? 
If you really fulfill the royal law according to the Scripture, "You shall love your neighbor as yourself," you are doing well. But if you show partiality, you are committing sin and are convicted by the law as transgressors.

Have you not then made distinctions among yourselves and become judges with evil thoughts?

\section{The Future of Race (Romans 8:20-23; 1 Corinthians 12:13 ESV)}

After this I looked, and behold, a great multitude that no one could number, from every nation, from all tribes and peoples and languages, standing before the throne and before the Lamb, clothed in white robes, with palm branches in their hands, and crying out with a loud voice, "Salvation belongs to our God who sits on the throne, and to the Lamb!"

For in one Spirit we were all baptized into one body-Jews or Greeks, slaves or free-and all were made to drink of one Spirit.

\section{Diagnosing and Treating the Sin of Racism}

The practice of assessment, diagnosis, and spiritual treatment of the human soul by the prayerful and studied application of Word, Sacrament, and Prayer remains the most potent method for human transformation (Milton 2016). Such a practice is called pastoring. The cure of souls is the God-ordained vocation and central mission of the Christian shepherd. For instance, we witness evidence of a veritable Balkanization (i.e., fragmenting) of America (and other Western and English-speaking nations, e.g., Australia) (Mestrovic 2004). Sadly, division and other pathologies of human society are an undeniable result of the poisonous presence of original and residual sins - the physical and metaphysical consequences of creaturely rebellion against the Creator-are well-known to the Christian shepherd and pastoral theologian. There is a particularly virulent and vicious strain of the sin of division: the degrading, dangerous, and highly infectious fracture between human beings because on based on accidental, non-contributing factors. We use the word accidental to describe those features, traits, and characteristics beyond one's control (we are certainly not asserting that life is an accident in the usual first-meaning that word).

One cannot choose certain physical features, one's bloodline, or even one's socio-economic or geographic place of origin. Therefore, to isolate and harass, or to hate a person or group in any way, based on the offended party's disdain for accidental causes in one's life is not only cruel but illogical. One's boorish behavior might put us off at a party. Still, such a factor is not accidental or inherited (though it is possible that no one ever taught the poor fellow about social etiquette). While possibly cruel or insensitive to the plight of another, we would, at least, be protesting a malleable factor. The poor fellow can change his ways. If, on the other hand, you were offended by the indelicacy of the man at the party because he was born with physical deformities, e.g., an irregular nervous system that caused him to spill his drink, you would be a fool. The man is incapable of choosing his physical qualities. Shout, jump up and down, or leave the party in disgust, but you cannot expect the poor fellow to change. Yet, you can do something. You could help him. Alternatively, you can ignore the man. You could even gather together a society for the hatred of those born with irregular nervous systems. However, your organization can never change the individual. Your club is only capable of prejudicial treatment of another based on disgust, spawned of pure, illogical hatred. The example is admittedly shallow. Yet, human beings routinely hate others based on their disdain for accidental factors: socio-economic classifications, sex (i.e., gender), religion, ethnicity, viz., race. Most of the epistles of the New Testament had their genesis in responding to the sin of division. Whether Corinth or Galatia, Rome or Ephesus, Christian communities fragmented because of external or superficial differences. Apostolic letters were then drafted and dispersed to the churches to correct the behavior and warn of God's wrath against such division.

Racism and other prejudicial actions were and are a result of sin, and the complexities of converging pathologies of the human soul. The cure is the open-hearted, forgiving, love of God in Christ. Consider this one 
passage citing the desire of Jesus, the Son of the Triune God, to leave His royal robes in heaven in order to abide with Man: (Philippians 2:5-8 NKJV).

Let this mind be in you which was also in Christ Jesus, who, being in the form of God, did not consider it robbery to be equal with God, but made Himself of no reputation, taking the form of a bondservant, and coming in the likeness of men. And being found in appearance as a man, He humbled Himself and became obedient to the point of death, even the death of the cross.

This is how we come to the passage that inaugurated our journey in this article, 1 John 4:20-21 (NKJV):

If someone says, "I love God," and hates his brother, he is a liar; for he who does not love his brother whom he has seen, how can he love God whom he has not seen? 21 And this commandment we have from Him: that he who loves God must love his brother also.

\section{Removing Racism}

So, we see that the Bible teaches that we were all of one race: the human race. There are differences, varieties, adaptations within the species, but we are all human beings. Therefore, for one person or group to ridicule, isolate, or injure another group of human beings because of accidental characteristics - variables within the human species they were born with - is a cruel and irrational response. Such tribalism promotes widespread division of people, degradation of humanity itself and makes the civil community at any level from the family to the city, to the nation - an impossible vision. Since such prejudicial language and hostile actions against people flow from the accidental traits they carry from birth, there can be no other assumption that the source of such prejudice is pure hatred that leads to division and division that leads to violence. Such societal confusion that breeds national fragmentation is a well-known chapter in the Marxist-Socialistanarchist's playbook. Books by communists in America have never hid their agendas (Ignatiev and Garvey 2007): "Make no mistake about it: we intend to keep bashing the dead white males, and the live ones, and the females too, until the social construct known as 'the white race' is destroyed-not 'deconstructed' but destroyed."

When we hate each other enough, an oppressive force then steps in to "heal" the breach. In thirty-two years of military service, including top-secret naval intelligence gathering and analysis in the Cold War, and the Chaplain Command of all Military Intelligence Readiness Command (MIRC) Army Chaplains posted around the globe, I have seen the devious plan at work. I have also witnessed the consequences. As a theologian and curator of the human soul, I know the damage done by racism and its wake of burning fuel for generations.

The Bible condemns racism as an assault on the image of God in humanity. For those who say that the clergy should just keep quiet in the sanctuary, I would remind us all that it was Dr. Martin Luther King, Jr. who was forced by history to make the matter the centering place of his vocation. Though a scholar, a Ph.D. in Religion, and a shepherd of souls, he sacrificed the life of a "vicar" for the role of a "prophet." It was the great John Donne, the preacher-poet of St. Paul's Cathedral who reminded us,

No man is an Island, entire of itself; every man is a piece of the Continent, a part of the maine; if a Clod be washed away by the Sea, Europe is the lessee, as well as if a Promontorie were, as well as if a Manner of thy friends or of thine owne were; any man's death diminishes me, because I am involved in Mankind; And therefore never send to know for whom the bell tolls; It tolls for thee.(Donne 1624)

Our love of God causes us to love others. Our calling as Christians causes us to speak. and act for those in danger. The unique vocation of the clergy requires that we "cry aloud and spare not" (Isaiah 58:1) when humanity is threatened by the vile threat of racism. Unfortunately, critical race theory, and books such as Ibram X. Kendi's 2019 book, How to Be an Antiracist, have become mainstream. The views are not only immature, poorly stated, and riddled with historical errors, but are also contrary to God's Word and, thus, harmful to human existence. Yet, their horrendous ideologies are being taught in grammar schools 
through professional postgraduate courses. There can be only one conclusion to normalizing hatred grounded in accidental differences in humankind: the loss of necessary, rational, civil discourse, which invariably leads to civil violence, and violence which leads to self-destruction. What is that conclusion? What must we do?

Offer the life of Jesus Christ who forgave us to others. Release the divine Word from Another World and the Spirit of God will convert, or, by judicial hardening of those who refuse Him, judge. I will challenge you to see how hatred of others withers when we see that we are of a race of sinners, under the judgment of our Creator, and desperately in need of a Savior. Therefore, I urge:

Receive God's love in Jesus Christ, and you will not only be protected from such corrosive ideologies as racism, but God will use the very thing that you used to stop God's love, to advance it. For good is stronger than evil, and the God who sent His Son to save one race, the race of humanity, will transform you.

How did your mother sing it to you when you were a child? Perhaps, the words are dated or unintentionally focused on color, suspect to stereotypical latent tendencies of an older, less sophisticated era. Nevertheless, the mother who would sing this to her wee lad or lass knew that the more prevalent sins of the heart that could strike at her child had to be faced, and had to be defeated on the most decisive battleground: the child's heart. Her chosen weapon for this spiritual warfare is the one we need now, more than ever: the love of God in Jesus Christ. Remember? I do.

"Jesus loves the little children, all of the children of the world; Red and yellow, black and white, they are precious in his sight; Jesus loves the little children of the world."

God's love in our hearts yields a harvest of love for others. This is how otherwise uncontrollable weeds of racism wither, and the new growth of life emerges, bringing peace, creating unity, and releasing the power of life as it was meant to be lived.

\section{References}

Bible, Holy. 1982. "The New King James Version". Nashville: Thomas Nelson Publishers.

Lindquist, Spencer. 2021. "Lecturer At Yale Fantasizes About Brutally Murdering White People". Journal Article. The Federalist. https://thefederalist.com/2021/06/04/lecturer-at-official-yale-eventfantasizes-about-brutally-murdering-white-people-claims-all-white-people-are-rotten/ .

Angelopoulou, Elli. 2001. "TitleUnderstanding the Color of Human Skin/Title". In Human Vision and Electronic Imaging VI, edited by Bernice E. Rogowitz and Thrasyvoulos N. Pappas. SPIE. https://doi. org/10.1117/12.429495.

Woodson Sr, Robert L. 2021. Red, White, and Black: Rescuing American History from Revisionists and Race Hustlers. Emancipation Books.

Relethford, John H. 1997. "Hemispheric Difference in Human Skin Color". Journal Article. American Journal of Physical Anthropology: The Official Publication of the American Association of Physical Anthropologists 104 (4): 449-57.

Bastiaens, Maarten, Jeanette ter Huurne, Nelleke Gruis, Wilma Bergman, Rudi Westendorp, Bert-Jan Vermeer, and Jan-Nico Bouwes Bavinck. 2001. "The Melanocortin-1-Receptor Gene Is the Major Freckle Gene". Journal Article. Human Molecular Genetics 10 (16): 1701-8.

Norton, David. 2005. The New Cambridge Paragraph Bible with the Apocrypha: King James Version. Cambridge University Press.

Sproul, Robert Charles. 2015. The Reformation Study Bible: English Standard Version. Reformation Trust.

Milton, Michael A. 2016. "Pastoral Assessment, Diagnosis, and Treatment of Congregational Pathologies". Erskine Theological Seminary. 
Mestrovic, S. 2004. The Balkanization of the West: The Confluence of Postmodernism and Postcommunism. Book. Taylor \& Francis. https://books.google.com/books?id=r7qHAgAAQBAJ .

Ignatiev, Noel, and John Garvey. 2007. "Abolish the White Race by Any Means Necessary". Race, Ethnicity, and Gender: Selected Readings, 448-51.

Donne, John. 1624. Meditation XVII: Devotion upon Emergent Occasions.

"Lecturer At Yale Fantasizes About Brutally Murdering White People". n.d. https://thefederalist.com/ 2021/06/04/lecturer-at-official-yale-event-fantasizes-about-brutally-murdering-whitepeople-claims-all-white-people-are-rotten. https://thefederalist.com/2021/06/04/lecturerat-official-yale-event-fantasizes-about-brutally-murdering-white-people-claims-allwhite-people-are-rotten/.

"The Smithsonian Institution's Human Origins Program". n.d. 